\title{
Compost and Compost Tea Management of Mini Watermelon Cultivations Affects the Chemical, Physical and Sensory Assessment of the Fruits
}

\author{
Loredana Liguori ${ }^{1}$, Catello Pane ${ }^{2}$, Donatella Albanese ${ }^{1 *}$, Giuseppe Celano ${ }^{3}$, \\ Massimo Zaccardelli2 ${ }^{2}$, Marisa Di Matteo ${ }^{1}$ \\ ${ }^{1}$ Dipartimento di Ingegneria Industriale, Università di Salerno, Fisciano, Italy \\ ${ }^{2}$ Consiglio per la Ricerca e la Sperimentazione in Agricoltura, Centro di Ricerca per l'Orticoltura, Pontecagnano, \\ Italy \\ ${ }^{3}$ Dipartimento delle Culture Europee e del Mediterraneo: Architettura, Ambiente, Patrimoni Culturali (DICEM), \\ Università degli Studi della Basilicata, Matera, Italy \\ Email: ${ }^{*}$ dalbanese@unisa.it
}

Received 4 December 2014; accepted 27 December 2014; published 16 January 2015

Copyright (C) 2015 by authors and Scientific Research Publishing Inc.

This work is licensed under the Creative Commons Attribution International License (CC BY). http://creativecommons.org/licenses/by/4.0/

(c) (i) Open Access

\begin{abstract}
Compost, rich in plant nutrients, is a readily available fertilizer with beneficial effects on physical, chemical, biochemical and biological properties of the soils. Moreover compost-based treatments can exert protective effects against plant diseases occurrence and/or stimulate an enhanced plant physiological status with improvements in quantity and quality of crop productions. In this study the effects of three different compost-based cropping managements on the productive response and main quality parameters of watermelon fruits were investigated. Treatments, in comparison with the conventional cultivation method, were: soil amendment with an agricultural waste compost (AWC), a municipal waste compost (MWC) and a foliar treatment with a compost tea blend (CTB). The productive responses and colour parameters related to compost treatments did not show significant differences compared to control ones, which reached a total yield of about 10.22 $\mathrm{kg} \cdot \mathrm{m}^{-2}$ with a mean weight of $2.74 \mathrm{~kg}$. AWC caused a higher ascorbic acid content with an increase of $50 \%$ than conventional treatment, while fruits obtained by CTB showed higher values in firmness and Quality Index than control samples. The analysis of main sugars highlighted that the application of compost as biofertilizer influenced the ratio among fructose, glucose and sucrose with respect to those observed for control fruits.
\end{abstract}

\footnotetext{
${ }^{*}$ Corresponding author.
}

How to cite this paper: Liguori, L., Pane, C., Albanese, D., Celano, G., Zaccardelli, M. and Di Matteo, M. (2015) Compost and Compost Tea Management of Mini Watermelon Cultivations Affects the Chemical, Physical and Sensory Assessment of the Fruits. Agricultural Sciences, 6, 117-125. http://dx.doi.org/10.4236/as.2015.61009 


\section{Keywords}

\section{Biostimulants, Compost, Quality, Watermelon}

\section{Introduction}

Among summer fruits, watermelons have a very high favour by consumers because to their high satiety index, low caloric intake and thirst-quenching and refreshing capability. In recent years, mini and seedless watermelons (Citrullus lanatus, Thunb.) have been developed to respond to the needs of small families, singles and consumers that have limited refrigerator space. The appeal to the mini watermelons can be further strengthened by the introduction of sustainable crop production, which gives an added value to the fruit. Increasing interest to food safety and environmental pollution has stimulated the attention for compost as valid alternative to the use of chemical fertilizers, beside the recovery of by-products from the refusals. Compost is the final product of the composting process, a solid state controlled microbial fermentation of organic and no degraded matters, which can include crop residues, animal wastes, food garbage, organic municipal and industrial wastes. Pane et al. [1] reported the beneficial effects of agricultural utilization of compost on physical, chemical, biochemical and biological properties of the soils. In the last years, the development of new products derived from compost, such as compost teas (CTs) is increasing, due to their positive effects on the crops [2]. CTs are organic products obtained through a liquid-phase compost extraction ranging from few hours to two weeks, with or without active aeration and the addition of nutrients (molasses, casein, etc.). Many researches have been focused on plant biostimulants due to the increasing attention about the use of natural substances to potentiate crop. In particular, both composts and compost teas can show this particular bioactivity on plants due to their content in aromatic, hormone-like organic molecules and useful microorganisms. Compost-based treatments, in fact, can exert protective effects against plant diseases occurrence [3] and/or stimulate an enhanced plant physiological status [2] with improvements in quantity and quality of crop productions. The most widely described uses of compost tea are related, almost exclusively, to its ability in suppressing plant pathogens [4]. Few papers regards the direct implication of compost-based treatments on the chemical, physical and, especially, on the sensory properties of vegetables such as lettuce [5], potato [6] and carrot systems [7] [8]. Thus further investigations are required to provide a clear information about the effects of compost and compost tea in promotion of eat quality among the worldwide consumed vegetables. Therefore this work, was focused on the effects of compost and compost tea on the main quality parameters of mini watermelons. To this aim, we hypothesized that the applied compost-based formulates may exert a suitable bioactivity on the plants related to the stimulation of quality parameters of the fruits.

\section{Materials and Methods}

\subsection{Greenhouse Trial}

Agronomic trials were carried out in 2012, under a greenhouse system in a loamy soil, at organic farm "IdeaNatura” located in Eboli (Salerno, Italy). The experimental design was a randomized complete block with plot areas of about $100 \mathrm{~m}^{2}$ each, replicated three times. Mini watermelon plants (cv Chicago) were transplanted on April $12^{\text {th }}$, on single raw, at distances of $0.50 \times 1.80 \mathrm{~m}$, in order to have a density of 1.10 plants $\cdot \mathrm{m}^{-2}$. Two different experiments based on the comparison among two compost and control amendments and between compost tea aerial spry treatments and not-treated plots were carried out. The compost treatments were:

- On-farm Agricultural Waste Compost (AWC), prepared from residues of corn, cabbage, fennel and salads mixed to wood chips [9];

- Municipal organic Waste Compost (MWC) purchased at Gesenu (Perugia, Italy);

- Compost Tea Blend (CTB) prepared by mixing (50\% vol.) two 1-week aerated teas produced by water extraction of artichoke and artichoke + fennel green composts (20\% vol.) [10].

Composts were applied at a dose necessary to supply $170 \mathrm{~kg} \cdot \mathrm{ha}^{-1}$ of nitrogen, thus 6 ton $\cdot \mathrm{ha}^{-1}$ of AWC $(\mathrm{N}=$ $2.8 \%)$ and 8.5 ton $^{-1} \mathrm{~h}^{-1}$ of MWC $(\mathrm{N}=2.8 \%)$ in dry weight, and were incorporated into the soil at a depth of 15 $\mathrm{cm}$. CTB, water diluted $10 \%$ vol., was weekly applied by spraying aerial parts of the plants. Total yield was de- 
termined in an assay area of about $11 \mathrm{~m}^{2}$ for each plot. For each compost treatment five fruits were analyzed for the evaluation of the main agronomical, chemical, physical and sensory parameters.

\subsection{Analyses}

Moisture and $\mathrm{pH}$ were determined in accordance with the Association of Official Analytical Chemists (AOAC) official methods [11]. Sugars were analyzed by HPLC system equipped with a $4.6 \times 250 \mathrm{~mm}$ steel Carbohydrate-Cartridge column (Waters, USA). The mobile phase was acetonitrile-water solution (75:25), with column at $30^{\circ} \mathrm{C}$ and $1 \mathrm{ml} / \mathrm{min}$ flow rate. Peaks were detected by a refractive index detector (Hewlett Packard, Agilent) and concentrations were calculated with external standards.

Ascorbic acid was determined by ion exchange chromatography according to Cinquanta et al. [12].

Firmness was measured by compression tests using a texturometer (Ametek Lloyd Instruments LRX plus, United Kingdom), with specific software (Nexygen batch 4.1). The size of watermelon samples analyzed was standardized with a cylinder cutter into pieces $2 \mathrm{~cm}$ in diameter and $1 \mathrm{~cm}$ in height. Firmness of watermelon samples was obtained from load and strain curves recorded during the compression of cylindrical samples to $50 \%$ of initial height, using two horizontal parallel plates, with the sample placed on the middle of the lower plate [13]. The crosshead speed was $50 \mathrm{~mm}$ per min with a cell load of $50 \mathrm{~N}$. Six repetitions from each watermelon sample and for five replicates, were performed. Colour of the flesh was measured with a CR-200 Chromometer (Minolta, Japan) having an aperture size of $10 \mathrm{~mm}$. Hunter values (L, $\mathrm{a}^{*}, \mathrm{~b}^{*}$ ) were monitored on the middle of half watermelon; three readings were obtained from each fruit for a total of fifteen measurements for each treatment [14]. Chroma $\left(C^{*}\right)$ is the saturation or vividness of colour. As chromaticity increases, a colour becomes more intense; as it decreases, a colour becomes more dull. Hue angle $\left(\mathrm{H}^{\circ}\right)$ is the basic unit of colour and can be interpreted, for example, as $0^{\circ}=$ red and $90^{\circ}=$ yellow. Both Chroma and Hue angle are derived from $a^{*}$ and $b^{*}$ using the following equations $C^{*}=\left(a^{2}+b^{2}\right)^{1 / 2} ; H^{\circ}=\arctan \left(b^{*} / a^{*}\right)$.

\subsection{Overall Quality Assessment}

A comprehensive survey of the sensory characteristics of colour of the pulp, crispness, sweetness, juiciness, mealinins and global odours of mini watermelons, was carried out. The intensity of the sensory terms was scored on nine-point structured scale ( $1=$ none; 9 = extreme). Random samples of different treatments were presented in three-digit coded plates and were separately evaluated by 12 untrained consumer panelists. The mean scores for each attribute were finally summed to give an overall sensory score known as the Quality Index (QI). For the calculation of QI, mealiness attribute was considered as negative value.

\subsection{Statistical Analysis}

All analyses were performed in triplicates. The average and standard deviation of each chemical, physical and sensory parameters results were subjected to a mono-factorial variance analysis (ANOVA), and the significance of differences $(\mathrm{P}<0.05)$ among means was determined with Fisher's Least Significant Difference (LSD) test. Statistical analysis was performed using an SPSS version 13.0 for Windows (SPSS, Inc., Chicago, IL, USA).

\section{Results}

\subsection{Productive Response}

The productive responses to AWC, MWC and CTB treatments, compared to their control plots, were reported in Table 1. The parameters investigated did not show substantial differences compared to control plots, which reached, on average, $10.22 \mathrm{~kg} \cdot \mathrm{m}^{-2}$. MWC soil amendment, instead, significantly reduced total yield $(-15 \%)$, likely due to an initial compost phytotoxicity that determined a slight growth reduction in the early phases of the cycle. Similarly, all the remaining measured agronomic traits of the fruits proved to be not affected by treatments.

\subsection{Quality Parameters}

The force corresponding to breakdown of the fruit tissue during compression test of flesh fruits was used as firmness of the mini watermelon samples. Fruit firmness and texture are most closely associated with cell wall 
Table 1. Effects of treatments with composts (a) and compost tea (b) on productive response of mini watermelon cropping system.

(a)

\begin{tabular}{|c|c|c|c|c|c|c|}
\hline \multirow{2}{*}{ Sample } & \multirow{2}{*}{$\begin{array}{l}\text { Total yield } \\
\left(\mathrm{kg} \cdot \mathrm{m}^{-2}\right)\end{array}$} & \multicolumn{5}{|c|}{ Fruits } \\
\hline & & $\begin{array}{l}\text { Weight } \\
\text { (kg) }\end{array}$ & $\mathrm{N}^{\circ} \mathrm{m}^{-2}$ & $\begin{array}{l}\text { Major diameter } \\
\text { (cm) }\end{array}$ & $\begin{array}{l}\text { Minor diameter } \\
\text { (cm) }\end{array}$ & $\begin{array}{l}\text { Pericarp thickness } \\
\text { (cm) }\end{array}$ \\
\hline CTRL & $9.82 \pm 0.27 \mathrm{a}$ & $3.12 \pm 1.12 \mathrm{a}$ & $4.44 \pm 0.64 a$ & $16.73 \pm 0.50 \mathrm{a}$ & $15.20 \pm 1.11 \mathrm{a}$ & $1.24 \pm 0.14 \mathrm{a}$ \\
\hline MWC & $8.70 \pm 0.98 a$ & $3.10 \pm 1.38 \mathrm{a}$ & $4.04 \pm 0.89 a$ & $16.67 \pm 0.11 \mathrm{a}$ & $15.65 \pm 0.60 \mathrm{a}$ & $1.14 \pm 0.11 \mathrm{a}$ \\
\hline AWC & $9.64 \pm 0.39 \mathrm{a}$ & $3.12 \pm 1.10 \mathrm{a}$ & $4.29 \pm 0.54 a$ & $16.73 \pm 0.42 a$ & $15.66 \pm 0.95 a$ & $1.23 \pm 0.17 \mathrm{a}$ \\
\hline
\end{tabular}

(b)

\begin{tabular}{ccccccc}
\hline Sample & $\begin{array}{c}\text { Total yield } \\
\left(\mathrm{kg} \cdot \mathrm{m}^{-2}\right)\end{array}$ & $\begin{array}{c}\text { Weight } \\
(\mathrm{kg})\end{array}$ & $\mathrm{N}^{\circ} \mathrm{m}^{-2}$ & $\begin{array}{c}\text { Major diameter } \\
(\mathrm{cm})\end{array}$ & $\begin{array}{c}\text { Minor diameter } \\
(\mathrm{cm})\end{array}$ & $\begin{array}{c}\text { Pericarp thickness } \\
(\mathrm{cm})\end{array}$ \\
\hline CTRL & $10.62 \pm 1.13 \mathrm{a}$ & $2.36 \pm 0.07 \mathrm{a}$ & $4.66 \pm 0.43 \mathrm{a}$ & $16.60 \pm 0.53 \mathrm{a}$ & $15.80 \pm 0.20 \mathrm{a}$ & $1.21 \pm 0.06 \mathrm{a}$ \\
CT & $9.42 \pm 1.27 \mathrm{a}$ & $2.90 \pm 0.59 \mathrm{a}$ & $4.02 \pm 0.51 \mathrm{a}$ & $16.53 \pm 1.28 \mathrm{a}$ & $15.62 \pm 1.22 \mathrm{a}$ & $1.18 \pm 0.11 \mathrm{a}$ \\
\hline
\end{tabular}

Different letters mean significant difference $(\mathrm{P}<0.05)$.

structure and composition. Firmness is determined largely by the physical anatomy of the tissue, particularly cell size, shape and packing, cell wall thickness and strength, and the extent of cell-to-cell adhesion, together with turgor status [15].

The comparison of firmness parameter detected on mini watermelon samples grown with and without different types of compost was shown in Table 2. CTB samples showed higher firmness when compared with its respective control, whereas MWC treatment exhibited the lowest $(\mathrm{P}<0.05)$ firmness than control and AWC. For these latter, no significant differences were found. Although differences were found in firmness values among samples, all mini watermelon samples firmness value ranged from 4.27 to $5.89 \mathrm{~N}$, in accordance with previous studies [16] [17].

Brittle properties of flesh fruits were recorded through rigidity value (Table 2). In this case, the CTB treatment did not show positive effect than the control, in contrast to AWC, that displayed the highest value.

The amount of the principal sugars (glucose, fructose and sucrose) detected in mini watermelon flesh cultivated by different treatments, was reported in Figure 1. Control samples exhibited higher sugar content than those treated by different types of compost. The concentration of these sugars changed in function of the treatment employed during the cultivation of the plant. In fact, the mini watermelon samples treated by composts showed low content of sucrose if compared with their respective control. Unlike CTB samples, where sucrose was found at higher amount than monosaccharide sugars, MWC and AWC samples showed fructose as the main sugar.

Colour parameters detected on the middle of the different watermelon samples were reported in Table 2. and were in the range recorded by Pardo et al. [18], who characterized the colour of 21 different cv of watermelon fruits in terms of L, a ${ }^{*}, b^{*}$, Chroma and Hue parameters. Statistical analysis carried out on colour parameters of fruit samples cultivated conventionally and using different type of compost, highlighted that all the samples showed similar values without significance differences among them.

The use of different types of compost, compared to conventionally cultivation, showed significant differences in vitamin C content (Table 2). AWC influenced positively the amount of ascorbic acid with an increase of 50\% than control. Opposite effect was, instead, observed in fruit samples treated by MWC and CTB, that exhibited significant $(\mathrm{P}<0.05)$ percentage decrease $(48 \%$ and $28 \%$ respectively) when compared to their respective control.

The quality assessment of mini watermelons was reported in Table 3, which highlighted some similarity with chemical and physical results. In fact, no significant differences were detected about the flesh colour among control and compost treated mini watermelons. Samples treated with AWC were perceived more odorous than MWC and control samples; similarly, CTB samples had a highly significant score $(P<0.05)$ in comparison with control samples. During tasting, mini watermelons presented some differences both for positive attributes, such 
Table 2. Colour, ascorbic acid content (mg/100g fw) and texture parameters detected on mini watermelons grown with different types of compost (agricultural waste compost AWC, municipal waste compost MWC (a) and a compost tea blend (CTB) (b).

(a)

\begin{tabular}{ccccccccc}
\hline Sample & $\mathrm{L}^{*}$ & $\mathrm{a}^{*}$ & $\mathrm{~b}^{*}$ & $\mathrm{C}^{*}$ & $\mathrm{H}^{\circ}$ & $\begin{array}{c}\text { Ascorbic acid } \\
(\mathrm{mg} / 100 \mathrm{~g} \text { fw })\end{array}$ & $\begin{array}{c}\text { Flesh } \\
\text { firmness (N) }\end{array}$ & $\begin{array}{c}\text { Flesh rigidity } \\
(\mathrm{KN} / \mathrm{m})\end{array}$ \\
\hline CTRL & $40.08 \pm 3.70 \mathrm{a}$ & $20.11 \pm 3.01 \mathrm{a}$ & $19.15 \pm 2.22 \mathrm{a}$ & $27.88 \pm 2.79 \mathrm{a}$ & $43.80 \pm 5.19 \mathrm{a}$ & $8.62 \pm 0.20 \mathrm{c}$ & $5.20 \pm 0.26 \mathrm{a}$ & $3.47 \pm 0.17 \mathrm{~b}$ \\
MWC & $39.40 \pm 2.42 \mathrm{a}$ & $22.27 \pm 1.13 \mathrm{a}$ & $18.74 \pm 1.70 \mathrm{a}$ & $29.13 \pm 1.69 \mathrm{a}$ & $40.04 \pm 2.38 \mathrm{a}$ & $5.84 \pm 0.15 \mathrm{~b}$ & $4.27 \pm 0.21 \mathrm{~b}$ & $3.29 \pm 0.16 \mathrm{~b}$ \\
AWC & $39.59 \pm 1.87 \mathrm{a}$ & $22.78 \pm 1.07 \mathrm{a}$ & $16.65 \pm 2.65 \mathrm{a}$ & $28.26 \pm 2.40 \mathrm{a}$ & $35.91 \pm 3.55 \mathrm{a}$ & $12.93 \pm 0.18 \mathrm{a}$ & $4.91 \pm 0.24 \mathrm{a}$ & $4.43 \pm 0.22 \mathrm{a}$ \\
\hline
\end{tabular}

(b)

\begin{tabular}{ccccccccc}
\hline Sample & $\mathrm{L}^{*}$ & $\mathrm{a}^{*}$ & $\mathrm{~b}^{*}$ & $\mathrm{C}^{*}$ & $\mathrm{H}^{\circ}$ & $\begin{array}{c}\text { Ascorbic acid } \\
(\mathrm{mg} / 100 \mathrm{~g} f \mathrm{f})\end{array}$ & $\begin{array}{c}\text { Flesh } \\
\text { firmness }(\mathrm{N})\end{array}$ & $\begin{array}{c}\text { Flesh rigidity } \\
(\mathrm{KN} / \mathrm{m})\end{array}$ \\
\hline CTRL & $36.42 \pm 3.01 \mathrm{a}$ & $21.49 \pm 3.58 \mathrm{a}$ & $15.08 \pm 4.29 \mathrm{a}$ & $27.64 \pm 4.31 \mathrm{a}$ & $34.38 \pm 4.10 \mathrm{a}$ & $8.23 \pm 0.15 \mathrm{a}$ & $4.12 \pm 0.21 \mathrm{~b}$ & $4.02 \pm 0.20 \mathrm{a}$ \\
$\mathrm{CTB}$ & $35.85 \pm 1.86 \mathrm{a}$ & $18.37 \pm 1.25 \mathrm{a}$ & $15.19 \pm 2.66 \mathrm{a}$ & $23.87 \pm 2.52 \mathrm{a}$ & $39.29 \pm 3.72 \mathrm{a}$ & $5.98 \pm 0.09 \mathrm{~b}$ & $5.89 \pm 0.29 \mathrm{a}$ & $4.27 \pm 0.21 \mathrm{a}$ \\
\hline
\end{tabular}

Different letters (a, b, c) mean significant difference $(\mathrm{P}<0.05)$.

Table 3. Quality assessment of mini watermelons grown with different types of compost (agricultural waste compost AWC, municipal waste compost MWC (a) and a compost tea blend (CTB) (b).

(a)

\begin{tabular}{cccccccc}
\hline Sample & Flesh colour & Global odours & Crispness & Juiciness & Sweetness & Mealiness & Quality Index \\
\hline Control & $7.00 \pm 0.35 \mathrm{a}$ & $6.71 \pm 0.38 \mathrm{ab}$ & $6.57 \pm 0.40 \mathrm{a}$ & $7.71 \pm 0.20 \mathrm{ab}$ & $7.43 \pm 0.38 \mathrm{a}$ & $1.57 \pm 0.20 \mathrm{a}$ & $33.86 \pm 1.8 \mathrm{a}$ \\
MWC & $7.33 \pm 0.63 \mathrm{a}$ & $6.33 \pm 0.30 \mathrm{~b}$ & $5.17 \pm 0.28 \mathrm{~b}$ & $6.15 \pm 0.35 \mathrm{~b}$ & $7.17 \pm 0.28 \mathrm{a}$ & $3.17 \pm 0.40 \mathrm{~b}$ & $30.3 \pm 1.4 \mathrm{~b}$ \\
AWC & $7.83 \pm 0.35 \mathrm{a}$ & $7.33 \pm 0.40 \mathrm{a}$ & $7.50 \pm 0.35 \mathrm{c}$ & $8.00 \pm 0.30 \mathrm{a}$ & $7.67 \pm 0.42 \mathrm{a}$ & $2.17 \pm 0.30 \mathrm{a}$ & $36.2 \pm 2.0 \mathrm{a}$ \\
\hline
\end{tabular}

(b)

\begin{tabular}{cccccccc}
\hline Sample & Flesh colour & Global odour & Crispness & Juiciness & Sweetness & Mealiness & Quality Index \\
CTRL & $8.00 \pm 0.26 \mathrm{~b}$ & $6.83 \pm 0.99 \mathrm{a}$ & $6.33 \pm 0.32 \mathrm{~b}$ & $7.50 \pm 0.35 \mathrm{~b}$ & $8.33 \pm 0.32 \mathrm{~b}$ & $4.50 \pm 0.38 \mathrm{~b}$ & $32.50 \pm 3.2 \mathrm{~b}$ \\
CTB & $9.00 \pm 0.63 \mathrm{a}$ & $8.00 \pm 0.53 \mathrm{a}$ & $7.83 \pm 0.41 \mathrm{a}$ & $8.67 \pm 0.52 \mathrm{a}$ & $8.83 \pm 0.41 \mathrm{a}$ & $2.33 \pm 0.30 \mathrm{a}$ & $40.00 \pm 1.3 \mathrm{a}$ \\
\hline
\end{tabular}

Different letters (a, b, c) mean significant difference $(\mathrm{P}<0.05)$.

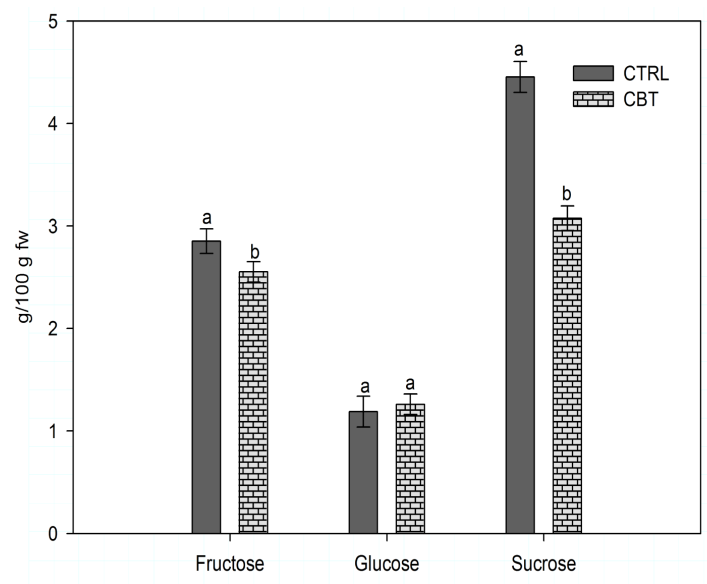

(a)

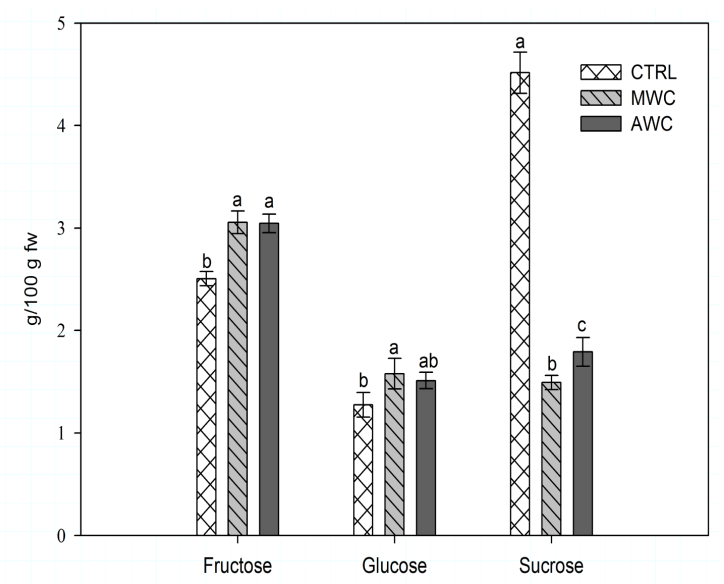

(b)

Figure 1. Sugars content (g/100g fw) in mini watermelon samples with different types of compost: (a) AWC and MWC; (b) CTB. 
as crispness, juiciness and sweetness, and negative ones like mealiness. In fact, it is worth noting that crispness of mini watermelons grown with AWC was significantly higher than control and MWC samples, which presented the lowest score. About juiciness, mini watermelons treated with AWC and MWC were different $(\mathrm{P}<$ 0.05 ) between them but not with respect to the control samples.

Mini watermelons grown with MWC had the highest score of mealiness with respect to AWC and control samples, which were perceived similarly. This tasting attributor affects negatively the Quality Index. The assessment of mini watermelons grown with CTB revealed significant differences $(P<0.05)$ when compared with its control, as regard crispness, juiciness and mealiness. In fact, CTB mini watermelons were crispier and juicier but less mealy than control samples. Lastly, CTB samples were preferred to the control ones, whereas AWC mini watermelons were preferred to MWC and control samples.

\section{Discussion}

Compost and compost teas are largely reported to be complementary to conventional methods of crop management for the enhancement of the quality associated to the agricultural products [19]. These results, for the first time, confirm this potential also on mini watermelon fruits, due to a general increase in some chemical, physical and sensory characteristics.

Sugars content together with colour of the flesh are the most important parameters that influence the consumer acceptability of mini watermelon fruits. As reported elsewhere [20] glucose, fructose and sucrose were the principal sugars in mini watermelon fruits. [21].

The kind and amount of various carbohydrates directly influence fruit flavour components, such as sweetness

Carbohydrate accumulation is closely related to stachyose metabolism [22], photosynthates translocation capacity in phloem [23] [24], galactose metabolism [25] and sucrose metabolism in the fruit [26]. The terminal sucrose metabolism is more important for its influence in the final carbohydrates accumulation [27]. Moreover, fructose and glucose accumulation happens in early stage fruit development, while sucrose ones occurs as a characteristic of its maturity [28] [29]. Lower sucrose concentration of mini watermelons fertilized with compost can be attributed to the slow release of nutrients and its unavailability at the critical stage of nutrient requirement.

Ascorbic acid (AA) has long been considered an important nutritional component of the fruits. The concentration of vitamin $C$ in watermelon's flesh depends on several factors such as cultivar, environmental conditions and cultural practices. In fact, it ranges from 38.2 - $69.8 \mathrm{mg} / \mathrm{kg} \mathrm{fw}$, as reported by Leskovar et al. [30], to 576.2 $\mathrm{mg} / \mathrm{kg} \mathrm{fw}$, as detected by Melo et al. [31]. Vitamin C concentration, detected in all mini watermelons differently treated, falls in the range reported in literature.

The differences found for vitamin C, but also for the other quality parameter investigated, among fruit samples treated by compost with respect to their control, may be attributed to a different concentration and/or release of potassium salt to the plant. Lester et al. [32] showed that firmness, total sugars and ascorbic acid were positively influenced in muskmelon fruits by a higher $\mathrm{K}$ salt application.

The efficacy of AWC soil amendment and CTB foliar spray were particularly evident on the qualitative intrinsic parameters of the fruits rather than on agronomic traits while, MWC decreased overall parametric set. Few previous studies concerning the use of the compost to grow plants of this species highlighted a low sensitive yield response to compost amendment [33], as well as more different effects depending by soil type and compost property [34]. Likely, this particular behaviour is due to the continue struggle between compost, promoting growth factors, and the appearance of allelopathy to which watermelon is reported to be very sensible [35] [36]. Nevertheless, it was showed that watermelon plants may receive benefits in term of protection from biotic adversities, from long-term compost soil applications [37]. Since compost and compost tea suppressiveness can play a crucial role in defense of plants from biotic stress, it may be also considerated as an indirect determinant of intrinsic and extrinsic crop quality [3] [10]. Moreover, here, it cannot be excluded that organic treatments have had, at used rates, only a biostimulant function in order to improve plant physiological status [2]. In agreement with previous findings carried out on tomato [38] and early potato [39] growing systems organic management may positively affects sensory quality and nutritional value of the products regardless of the yield. Similarly, Vogtmann et al. [40] reported an improvement of food quality and storage performance of some vegetables induced by compost without any particular effects on the quantity. Concerning the compost tea, 
Fayed [41] and Stino et al. [42] reported the enhancement of physical and chemical traits of pomegranate and peaches, respectively, following aerial applications on trees. The authors, in order to explain the observations, agreed on a nutriactive hypothesis based on the increased assumption of microelements by foliar feeding. Here, sensory evaluation revealed that AWC and CTB application gave increased acceptance of fresh-cut mini watermelon, suggesting that compost-based formulates could contribute to improve the sensory quality by enhancing fruit aroma attributes. Previously, Radovich et al. [43] reported the capability of a compost to affect positively flavour and aroma intensity in basil. In mini watermelon extracts, volatile aliphatic aldehydes and alcohols, were described to be the most bioactive molecules responsible for odour and consumers acceptance [44] [45]. Here, it is possible to hypothesize the involvement of compost-based treatments in stimulation of secondary metabolites biosynthesis. Accordingly, Siddiqui et al. [46] found that compost tea treatments caused an increase in the concentration of terpenoid-related compounds in the aromatic medicinal herb, Centella asiatica. From this point of view, further investigations about the influence of compost and compost tea treatment on the volatile compounds that affect the aroma flavour of vegetable products are necessary.

\section{Conclusion}

The results of this study highlighted that two compost amendments and a compost tea aerial spry treatments did not change growth and yield factor of the crop. Compost-based treatments seemed to influence the quantitative profile of sugars of the fruits even if the sweetness, judged by the panelists did not show significant differences among the samples. Compost tea, specifically, provided improvement for Quality Index which represented the overall sensory score of the watermelons and thus higher preferences by the consumers. The data obtained in this study allowed presuming that the compost and compost tea should be used as a valid and promising alternative to the use of chemical stimulants in mini watermelon cropping systems.

\section{Acknowledgements}

Greenhouse trial of this research was supported by the "BioCompost" Project, funded by the PSR 2007/2013 European funding programme (F.E.A.S.R., Measure 124).

\section{References}

[1] Pane, C., Villecco, D. and Zaccardelli, M. (2013) Short-Time Response of Microbial Communities to Waste Compost Amendment of an Intensive Cultivated Soil in Southern Italy. Communications in Soil Science and Plant Analysis, 44, 2344-2352. http://dx.doi.org/10.1080/00103624.2013.803566

[2] Zaccardelli, M., Pane, C., Scotti, R., Palese, A.M. and Celano, G. (2012) Use of Compost-Tea as Bio-Agrochemicals and Bio-Stimulants in Horticulture. Italus Hortus, 19, 17-28.

[3] Pane, C., Piccolo, A., Spaccini, R., Celano, G., Villecco, D. and Zaccardelli, M. (2013) Agricultural Waste-Based Composts Exhibiting Suppressivity to Diseases Caused by the Phytopathogenic Soil-Borne Fungi Rhizoctonia solani and Sclerotinia minor. Applied Soil Ecology, 65, 43-51. http://dx.doi.org/10.1016/j.apsoil.2013.01.002

[4] Scheuerell, S.J. and Mahaffee, W.F. (2002) Compost Tea: Principles and Prospects for Plant Disease Control. Compost Science and Utilization, 10, 313-338. http://dx.doi.org/10.1080/1065657X.2002.10702095

[5] Masarirambi, M.T., Hlawe, M.M., Oseni, O.T. and Sibiya, T.E. (2010) Effects of Organic Fertilizers on Growth, Yield, Quality and Sensory Evaluation of Red Lettuce (Lactuca sativa L.) "VenezaRoxa". Agriculture and Biology Journal of North America, 1, 1319-1324. http://dx.doi.org/10.5251/abjna.2010.1.6.1319.1324

[6] Wszelaki, A.L., Delwiche, J.F., Walker, S.D., Ligget, R.E., Scheerens, J.C. and Kleinhenz, M.D. (2005) Sensory Quality and Mineral and Glycoalkaloid Concentrations in Organically Grown Redskin Potatoes (Solanum tuberosum). Journal of Agriculture and Food Chemistry, 85, 720-726. http://dx.doi.org/10.1002/jsfa.2051

[7] Haglund, A., Johansson, L., Berglund, L. and Dahlstedt, L. (1999) Sensory Evaluation of Carrots from Ecological and Conventional Growing Systems. Food Quality and Preference, 10, $23-29$. http://dx.doi.org/10.1016/S0950-3293(98)00034-2

[8] Gilsenan, C., Burke, R.M., Barry, R.C., O’Sullivan, G. and Pierce, E. (2008) An Evaluation of the Sensory Properties of Irish Grown Organic and Conventional Carrots (Daucus carota L.) and Mushrooms (Agaricus bisporus). School of Culinary Arts and Food Technology, Dublin.

[9] Zaccardelli, M., Villecco, D., Pane, C., Ragosta, G., Palese, A.M. and Celano, G. (2012b) “On Farm” Composting of Vegetable Residues. Proceeding of the ISWA World Solid Waste Congress, Firenze, 17-19 September. 
[10] Pane, C., Celano, G., Villecco, D. and Zaccardelli, M. (2012) Control of Botrytis cinerea, Alternaria alternata and Pyrenochaeta lycopersici on Tomato with Whey Compost-Tea Applications. Crop Protection, 38, 80-86. http://dx.doi.org/10.1016/j.cropro.2012.03.012

[11] AOAC (1990) Official Methods of Analysis. 15th Edition, Association of Official Analytical Chemists, Arlington.

[12] Cinquanta, L., Albanese, D., Cuccurullo, G. and Di Matteo, M. (2010) Effect on Orange Juice of Batch Pasteurization in an Improved Pilot-Scale Microwave Oven. Journal of Food Science, 75, 46-50. http://dx.doi.org/10.1111/j.1750-3841.2009.01412.x

[13] Cuccurullo, G., Giordano, L., Albanese, D., Cinquanta, L. and Di Matteo, M. (2012) Infrared Thermography Assisted Control for Apples Microwave Drying. Journal of Food Engineering, 112, 319-325. http://dx.doi.org/10.1016/j.jfoodeng.2012.05.003

[14] Albanese, D., Cinquanta, L., Cuccurullo, G. and Di Matteo, M. (2013) Effects of Microwave and Hot-Air Drying Methods on Colour, $\beta$-Carotene and Radical Scavenging Activity of Apricots. International Journal of Food Science and Technology, 48, 1327-1333. http://dx.doi.org/10.1111/ijfs.12095

[15] Harker, F.R., Stec, M.G.H., Hallett, I.C. and Bennett, C.L. (1997) Texture of Parenchymatous Plant Tissue: A Comparison between Tensile and Other Instrumental and Sensory Measurements of Tissue Strength and Juiciness. Postharvest Biology and Technology, 11, 63-72. http://dx.doi.org/10.1016/S0925-5214(97)00018-5

[16] Mao, L., Karakurt, Y. and Huber, D.J. (2004) Incidence of Water-Soaking and Phospholipid Catabolism in Ripe Watermelon (Citrullus lanatus) Fruit: Induction by Ethylene and Prophylactic Effects of 1-Methylcyclopropene. Postharvest Biology and Technology, 33, 1-9. http://dx.doi.org/10.1016/j.postharvbio.2003.12.007

[17] Ramos-Villarroel, A.Y., Aron-Mafteib, N., Martín-Bellosoc, O. and Soliva-Fortunyc, R. (2012) Influence of Spectral Distribution on Bacterial Inactivation and Quality Changes of Fresh-Cut Watermelon Treated with Intense Light Pulses. Postharvest Biology and Technology, 69, 32-39. http://dx.doi.org/10.1016/j.postharvbio.2012.03.002

[18] Pardo, J.E., Gómez, R., Tardáguila, J., Amoz, M.R. and Váron, R. (1997) Quality Evaluation of Watermelon Varties (Citrullus vulgaris s.). Journal of Food Quality, 20, 547-557. http://dx.doi.org/10.1111/j.1745-4557.1997.tb00495.x

[19] Naidu, Y., Meon, S. and Siddiqui, Y. (2013) Foliar Application of Microbial-Enriched Compost Tea Enhances Growth, Yield and Quality of Muskmelon (Cucumis melo L.) Cultivated under Fertigation System. Science Horticolturae, 159, 33-40. http://dx.doi.org/10.1016/j.scienta.2013.04.024

[20] Rouphael, Y., Schwarz, D., Krumbein, A. and Colla, G. (2010) Impact of Grafting on Product Quality of Fruit Vegetables. Science Horticolturae, 127, 172-179. http://dx.doi.org/10.1016/j.scienta.2010.09.001

[21] Xu, C.Q., Li, T.L. and Qi, H.Y. (2006) Effects of Grafting on Development, Carbohydrate Content, and Sucrose Metabolizing Enzymes Activities of Muskmelon Fruit. Acta Horticolturae Sinica, 33, 773-778.

[22] Taji, T., Ohsumi, C., Iuchi, S., Seki, M., Kasuga, M. and Kobayashi, M. (2002) Important Roles of Drought- and Cold-Inducible Genes for Galactinol Sythase in Stress Tolerance in Arabidopsis thaliana. Plant Journal, 29, 417-426. http://dx.doi.org/10.1046/j.0960-7412.2001.01227.x

[23] Li, T.L. (2000) Relation between the Vascular System and Photosynthate Translocation Pathways in Tomato Plants. Journal of the Japanese Society for Horticultural, 69, 69-75. http://dx.doi.org/10.2503/jishs.69.69

[24] Brian, G.A., Felix, K. and Robert, T. (2003) Symplastic Continuity between Companion Cells and the Translocation Stream: Long-Distance Transport Is Controlled by Retention and Retrieval Mechanisms in the Phloem. Journal of Plant Physiology, 13, 1518-1528.

[25] Dai, N., Petreikov, M., Portnoy, V., Katzir, N., Pharr, D.M. and Schaffer, A. (2006) Cloning and Expression Analysis of a UDP Galactose/Glucose Pyrophosphorylase from Melon Fruit Provides Evidence for the Major Metabolic Pathway of Galactose Metabolism in Raffinose Oligosaccharide Metabolizing Plants. Journal of Plant Physiology, 142, 294-304. http://dx.doi.org/10.1104/pp.106.083634

[26] Lingle, S.E. and Dunlap, J.R. (1987) Sucrose Metabolism in Netted Muskmelon Fruit during Development. Journal of Plant Physiology, 84, 386-389. http://dx.doi.org/10.1104/pp.84.2.386

[27] Zhang, M.F., Li, Z.L., Chen, K.S., Qian, Q.Q. and Zhang, S.L. (2003) The Relationship between Sugar Accumulation and Enzymes Related to Sucrose Metabolism in Developing Fruits of Muskmelon. Acta Physiologica Sinica, 29, 455462.

[28] Gross, K.C. and Pharr, D.M. (1982) A Potential Pathway for Galactose Metabolism in Cucumis sativus L., A Stachyose Transporting Species. Journal of Plant Physiology, 69, 117-121. http://dx.doi.org/10.1104/pp.69.1.117

[29] Studer Feusi, M.E., Burton, J.D., Williamson, J.D. and Mason Pharr, D. (1999) Galactosyl-Sucrose Metabolism and UDP-Galactose Pyrophosphorylase from Cucumis melo L. Fruit. Physiologia Plantarum, 106, 9-16. http://dx.doi.org/10.1034/j.1399-3054.1999.106102.x

[30] Leskovar, D.I., Bang, H.J., Crosby, K., Maness, N., Franco, J.A. and Perkins-Veazie, P. (2004) Lycopene, Carbohy- 
drates, Ascorbic Acid, and Yield Components of Diploid and Triploid Watermelon Cultivars Are Affected by Deficit Irrigation. The Journal of Horticultural Science and Biotechnology, 79, 75-81.

[31] Melo, E.A., Lima, V.L.A.G., Maciel, M.I.S., Caetano, A.C.S. and Leal, F.L.L. (2006) Polyphenol, Ascorbic Acid and Total Carotenoid Contents in Common Fruits and Vegetables. Brazilian Journal of Food Technology, 9, 89-94.

[32] Lester, G.E., Jifon, J.L. and Rogers, G. (2005) Supplemental Foliar Potassium Application during Muskmelon Fruit Development Can Improve Fruit Quality, Ascorbic Acid and Beta Carotene Contents. Journal of the American Society for Horticultural Science, 130, 649-653.

[33] Lu, W., Yang, X., Sibley, J.L., Caylor, A.W., Foshee, W.G., Zhang, Y., Bannon, J.S. and Gilliam, C.H. (2008) Mixed Municipal Solid Waste Compost as a Soil Amendment on Yield and Heavy Metal Accumulation in Okra and Watermelon. International Journal of Vegetable Science, 14, 369-379. http://dx.doi.org/10.1080/19315260802307256

[34] Huel, N.V. and Mai, Y. (2002) Manganese Toxicity in Watermelon as Affected by Lime and Compost Amended to a Hawaiian Acid Oxisol. Hort Science, 37, 656-661.

[35] Hao, Z.P., Wang, Q., Christie, P. and Li, X.L. (2007) Allelopathic Potential of Watermelon Tissues and Root Exudates. Science Horticolturae, 112, 315-320. http://dx.doi.org/10.1016/j.scienta.2006.12.030

[36] de Albuquerque, M.B., dos Santos, R.C., Lima, L.M., Melo Filho, P.A., Nogueira, R.J.M.C., da Câmara, C.A.G. and Ramos, A.R. (2011) Allelopathy, an Alternative Tool to Improve Cropping Systems. A Review. Agronomy for Sustainable Development, 31, 379-395. http://dx.doi.org/10.1051/agro/2010031

[37] Hozores-Hampton, M., McSorley, R. and Stansly, P.A. (2012) Effects of Long-Term Organic Amendments and Soil Sanitation on Weed and Nematode Populations in Pepper and Watermelon Crops in Florida. Crop Protection, 41, 106112. http://dx.doi.org/10.1016/j.cropro.2012.03.017

[38] Thybo, A.K., Edelenbos, M., Christensen, L.P., Sørensen, J.N. and Thorup-Kristensen, K. (2006) Effect of Organic Growing Systems on Sensory Quality and Chemical Composition of Tomatoes. LWT_Food Science and Technology, 39, 835-843.

[39] Lombardo, S., Pandino, G. and Mauromicale, G. (2012) Nutritional and Sensory Characteristics of "Early" Potato Cultivars under Organic and Conventional Cultivation Systems. Food Chemistry, 133, 1249-1254. http://dx.doi.org/10.1016/j.foodchem.2011.10.005

[40] Vogtmann, H., Matthies, K., Kehres, B. and Meier-Ploeger, A. (1993) Enhanced Food Quality: Effects of Composts on the Quality of Plant Foods. Compost Science and Utilization, 1, 82-100. http://dx.doi.org/10.1080/1065657X.1993.10771129

[41] Fayed, T.A. (2010) Effect of Compost Tea and Some Antioxidant Applications on Leaf Chemical Constituents, Yield and Fruit Quality of Pomegranate. World Journal of Agricultural Sciences, 6, 402-411.

[42] Stino, R.G., Fayed, T.A., Ali, M.M. and Alaa, S.A. (2010) Enhancing Fruit Quality of Florida Prince Peaches by Some Foliar Treatments. Journal of Horticolturae Science and Ornamental Plants, 2, 38-45.

[43] Radovich, T.J., Cavaletto, C.G. and Valenzuela, H.R. (2000) Effect of Compost and Mineral Fertilizer Applications on the Sensory Quality of Basil (Ocium basilicum L.). Hort Science, 35, 465-472.

[44] Genthner, E.R. (2010) Identification of Key Odorants in Fresh-Cut Watermelon Aroma and Structure-Odor Relationships of Cis,cis-3,6-nonadienal and Ester Analogs with Cis,cis-3,6-nonadiene, Cis-3-nonene and Cis-6-nonene Backbone Structures. Thesis, University of Illinois at Urbana-Champaign, Urbana-Champaign.

[45] Pino, J., Marbot, R. and Aguero, J. (2003) Volatile Components of Watermelon (Citrullus lanatus [Thunb.] Matsum. et Nakai) Fruit. Journal of Essential Oil Research, 15, 379-380. http://dx.doi.org/10.1080/10412905.2003.9698616

[46] Siddiqui, Y., Islam, T.M., Naidu, Y. and Meon, S. (2011) The Conjunctive Use of Compost Tea and Inorganic Fertilizer on the Growth, Yield and Terpenoid Content of Centella asiatica (L.) Urban. Science Horticolturae, 130, 289-295. http://dx.doi.org/10.1016/j.scienta.2011.05.043 
Scientific Research Publishing (SCIRP) is one of the largest Open Access journal publishers. It is currently publishing more than 200 open access, online, peer-reviewed journals covering a wide range of academic disciplines. SCIRP serves the worldwide academic communities and contributes to the progress and application of science with its publication.

Other selected journals from SCIRP are listed as below. Submit your manuscript to us via either submit@scirp.org or Online Submission Portal.
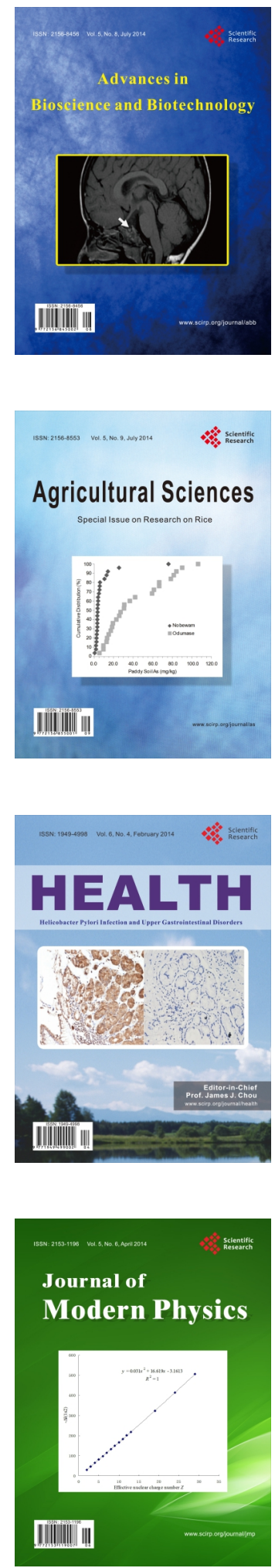
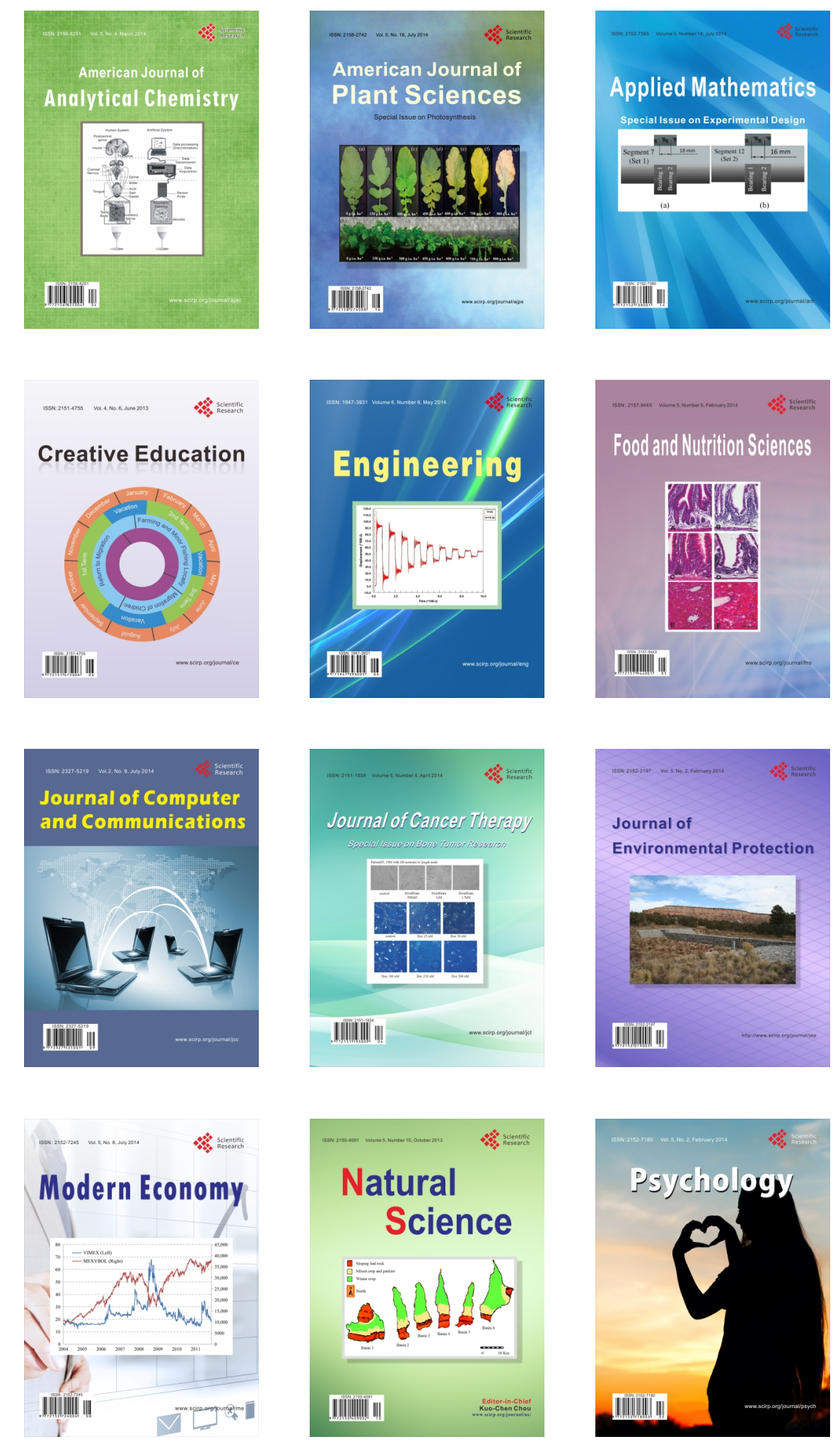